\title{
Cement Kiln Dust Chemical Stabilization of Expansive Soil Exposed at El-Kawther Quarter, Sohag Region, Egypt
}

\author{
Hesham A. H. Ismaiel \\ Geology Department, Faculty of Science, South Valley University, Qena, Egypt \\ Email: heshahmed@yahoo.com
}

Received September 10, 2013; revised October 12, 2013; accepted November 5, 2013

Copyright (C) 2013 Hesham A. H. Ismaiel. This is an open access article distributed under the Creative Commons Attribution License, which permits unrestricted use, distribution, and reproduction in any medium, provided the original work is properly cited. In accordance of the Creative Commons Attribution License all Copyrights (C) 2013 are reserved for SCIRP and the owner of the intellectual property Hesham A. H. Ismaiel. All Copyright (C) 2013 are guarded by law and by SCIRP as a guardian.

\begin{abstract}
This work dealt with a chemical stabilization of an expansive high plastic soil of Pliocene deposits exposed at El-Kawther quarter using cement kiln dust (CKD) and cement kiln dust with lime (L) to reduce their swelling and improve their geotechnical properties. Several specimens of the studied expansive soil were collected from El-Kawther quarter. Chemical analysis of the used cement kiln dust and the lime was conducted. Microstructural changes were examined using scanning electron microscope (SEM) before and after chemical treatment of the studied soil. Geotechnical properties including plasticity, compaction parameters, unconfined compressive strength (qu), ultrasonic velocities and free swelling of the studied soil were measured before and after the treatment. An optimum content of the cement kiln dust was $16 \%$ (CKD). The optimum content of the cement kiln dust with the lime was 14\% (CKD) with 3\% (L) according to $\mathrm{pH}$-test. The results showed that the addition of cement kiln dust and cement kiln dust with lime led to a decrease in maximum dry density and an increase in optimum water content. Unconfined compressive strength values were increased using cement kiln dust and cement kiln dust with lime at 7 days curing time. Ultrasonic longitudinal (Vp) and shear (Vs) velocities values were also increased by addition of the cement kiln dust and the cement kiln dust with lime at 7 days curing time. Increment of the curing time from 7 to 28 days led to an increase in both unconfined compressive strength and ultrasonic velocities values. Free swelling percent of the studied soil was reduced from $80.0 \%$ to $0.0 \%$ after the treatment.
\end{abstract}

Keywords: Ultrasonic Velocities; Free Swelling; Heave; Unconfined Compressive Strength and Microstructural Changes

\section{Introduction}

Environmental conditions (arid or humid regions) are major factor affecting swelling behavior of the expansive soils. The desert area as arid region (at El-Kawther quarter east Sohag city, Figure 1) is the most promising area for development of territories outside the Nile valley. The sediments of the arid region are characterized by an occurrence of expansive clay minerals; these clays may lead to a heave of the roads construction. For this reason, there is urgency to treat the expansive clayey soils to avoid the heave [1]. The chemical stabilization of the problematic soils (expansive soils and soft fine-grained soils) is very important for many of the geotechnical engineering applications such as pavement structures, roadways, building foundations, channel and reservoir linings, irrigation systems, water lines and sewer lines to avoid the damage due to the swelling action (heave) of the expansive soils or the settlement of the soft soils [2].

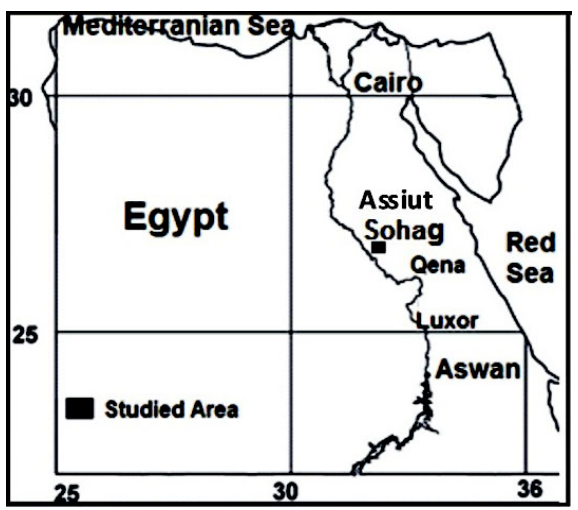

Figure 1. Location map of the studied area. 
In Egypt, lime was used in-situ chemical stabilization of expansive clay soil at New Valley Governorate [3]. An addition of lime slurry showed an improvement of physical and chemical soils properties with respect to the heave [3].

Cement kiln dust is a by-product in the production of Portland cement clinker. Disposal of cement kiln dust is an environmental problem. The utilization of this waste material has received increasing attention because it not only solves a potential solid waste problem but also provides an alternative stabilizing agent using in chemical stabilization of problematic soils and provides an alternative construction material. The use of the cement kiln dust for chemical stabilization applications may be an environmental solution of the problems associated with its disposal process where a very huge amount of the cement kiln dust as by-product is daily produced from the cement factories in Egypt. The composition of the cement kiln dust is similar to raw materials of cement but the amount of alkalis, chlorides and sulfates is usually considerably higher in the cement kiln dust [4]. Cement kiln dust is not a hazardous waste material under united state environmental protection agency guidelines [5].

A roadway section consists of a complete pavement system [6] shown in Figure 2. The sub-grade refers to the in situ soils on which the stresses from the overlying roadway will be distributed. The sub-base or sub-base course and the base or base course materials are stress distributing layer overlying sub-grade layer and underlying of the pavement layer. The pavement structure consists of a relatively thin wearing surface constructed over a base course and a sub-base course, which rests upon an in situ sub-grade. The wearing surface is primarily asphalt layer.

The quality of the sub-grade soils used in pavement application is classified into 5 types (soft, medium, stiff, very stiff and hard sub-grade) depending on unconfined compressive strength values [7]. The sub-grade soils, which are classified as A7-5 and A7-6, have general rating as fair to poor according to American association of state highway and transportation officials (AASHTO). These types are considered as unstable sub-grades and need to be improved and stabilized, especially in terms of pavement applications [8]. Sub-grade soil of the studied area is an expansive and leads to the heave.

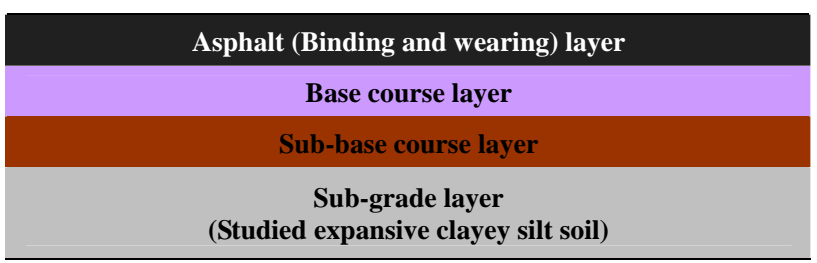

Figure 2. A typical flexible pavement structure.

\subsection{Location of Study Area}

The study area (El-Kawther quarter, east Sohag city) lies between old flood plain and El-Maaza limestone plateau. It lies between latitudes $26^{\circ} 30^{\prime} \mathrm{N}$ and $26^{\circ} 45^{\prime} \mathrm{N}$ and longitudes $31^{\circ} 45^{\prime} \mathrm{E}$ and $32^{\circ} 00^{\prime} \mathrm{E}$ (Figure 1). Two sections at El-Kawther sector were studied. The location of the first section is at $1 \mathrm{~km}+400 \mathrm{~m}$ and the second one at $3 \mathrm{~km}+$ $100 \mathrm{~m}$ in the northwest direction.

\subsection{Previous Studies}

Many geological investigations were carried out on the study area like [9-13] and others.

Few geotechnical investigations for lime chemical stabilization in the studied area and in Egypt were achieved like [3] (at Idku city), [14] (at Toshka area), [15] (at New Valley Governorate) and [1] (at El-Kawther area).

\subsection{Scope of Present Study}

This work dealt with an investigation of the geotechnical properties of an expansive high plastic clayey silt soil at El-Kawther quarter (Sohag region). The studied soil occurred as sub-grade of upper Egypt-Red Sea (SohagSafaga) road. The main goal of this study was a chemical stabilization program of the studied sub-grade soil using cement kiln dust and cement kiln dust with hydrated lime to reduce its swelling (Figure 3) and improve its geotechnical properties. Finally, the increasing trend towards cement production, in Egypt, through limestone/shale and/or marl combustion has aggravated the problems associated with the disposal of the cement kiln dust (byproduct), so that the use of the cement kiln dust as a stabilizing agent play an environmental and economical role. Economically, use of cement kiln dust as a chemical additive in chemical soil stabilization and for geotechnical applications is cheaper than Portland cement and other (expansive) chemical stabilization. Environmentally, reuse of the cement kiln dust for soil chemical stabilization

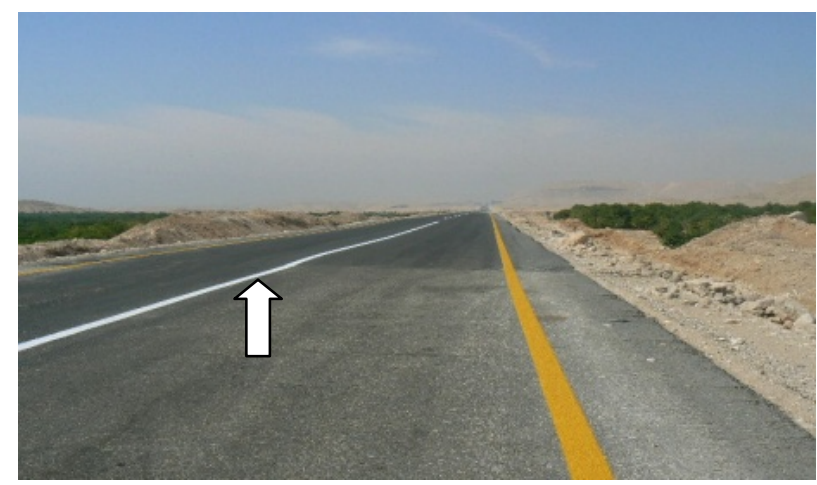

Figure 3. A heave in asphalt layer of the studied road due to swelling of the expansive soil sub-grade at El-Kawther sector. 
may be a solution of the environmental problems associated with its disposal process where a very huge amount of the cement kiln dust as by-product are daily produced from the cement factories in Egypt.

\section{Geological Setting of Study Area}

Geology of the studied area is characterized by a large carbonate plateau called El-Maaza plateau and several terraces of variable levels intercalated occasionally by marl and carbonate sediments and covered with Quaternary sediments. The distribution of the sediments is mapped in some details in a geological map as shown in Figure 4. El-Maaza plateau which belongs to Eocene age is characterized by low relief topography with general inclination towards the west direction. The high of plateau reaches to $560 \mathrm{~m}$ above sea level [1]. The carbonate plateau is dissected by a number of Wadis running in a general NW-SE direction. Some of these Wadis are run in the direction of the general topographic slope and parallel to the Nile valley and other streams run in the direction opposite to both dips of the formations and the consequent streams. The major wadis dissecting the limestone plateau (East Sohag) are summarized as Wadi Abu Nafukh, Wadi Kiman, and Wadi Dir El-Hadied which connect with river Nile [10]. The studied soil (expansive high plastic clayey silt) is belonging to Issawia Formation having Pliocene age. Issawia Formation is composed of chocolate brown clay and silt. It overlies older strata mostly Eocene and underlies alluvial deposits of Pleistocene age [16].

\section{Materials and Methods}

\subsection{Materials}

Fourty two specimens of the studied expansive soils were collected from the two sections exposed at El-Kawther sector as a part of the upper Egypt-Red Sea (SohagSafaga) road, east of Sohag city. The studied soil represented the sub-grade of Sohag-Safaga road at El-Kawther sector. It was composed of fine sand (20.00\%), silt (55.00\%) and clay (25.00\%). This clayey silt is classified as $(\mathrm{MH})$ according to Unified Soil Classification System (USCS) and as A7-5 according to AASHTO and it is poor to fair as sub-grade. The studied expansive soil is mainly composed of silica, iron, aluminum and calcium. The mineralogical composition of studied the expansive soil is clay $(37.70 \%)$, calcite $(27.80 \%)$, quartz (23.5\%), gypsum (7.90\%) and Hematite (3.10\%). The soluble salts of the studied soil including sulfates and chlorides are $0.01 \%$ and $0.04 \%$ respectively [1]. In the present study, cement kiln dust and cement kiln dust with hydrated lime were used for chemical stabilizing of the studied expansive clayey silt soil. The chemical composition of the used cement kiln dust and the hydrated lime was illustrated in Table 1. Cement kiln dust is by-product from Qena cement plant which lies at industrial Qift city. Huge amount of the cement kiln dust (180 Tons) is daily produced. The cement kiln dust is non-plastic fine grained materials having silt size grains. The chemical analysis showed that it was mainly composed of the oxides of calcium, aluminium, iron and silica. Hydrated lime is

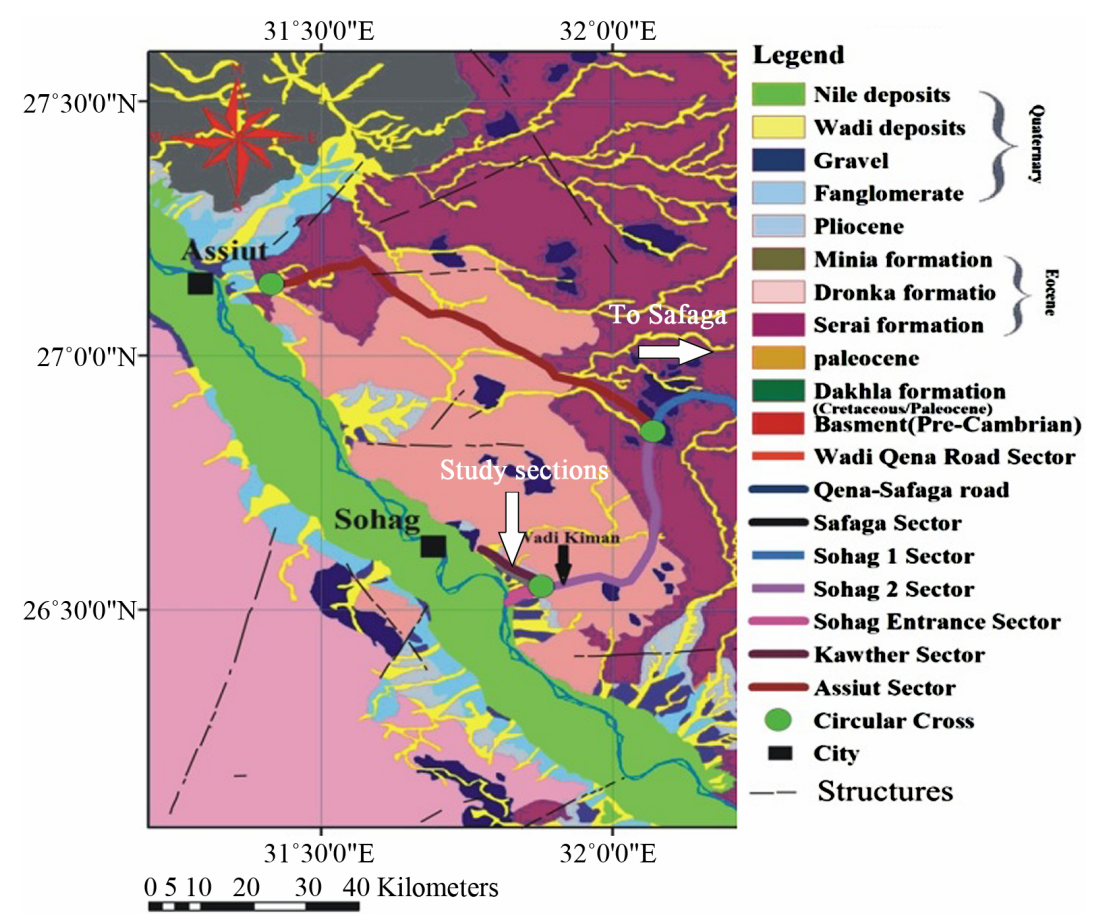

Figure 4. Geological map of the studied area modified after [1]. 
Table 1. Chemical composition of the used cement kiln dust and the hydrated lime.

\begin{tabular}{ccccccccccccc}
\hline Chemical oxides (\%) & $\mathrm{MgO}$ & $\mathrm{Al}_{2} \mathrm{O}_{3}$ & $\mathrm{SiO}_{2}$ & $\mathrm{~K} 2 \mathrm{O}$ & $\mathrm{CaO}$ & $\mathrm{TiO}_{2}$ & $\mathrm{Fe}_{2} \mathrm{O}_{3}$ & $\mathrm{P}_{2} \mathrm{O}_{5}$ & $\mathrm{Na}_{2} \mathrm{O}$ & $\mathrm{SO}_{3}$ & $\mathrm{Cl}$ & $\mathrm{LOI}^{2}$ \\
Type of additive & 0.78 & 5.13 & 16.96 & 1.18 & 57.39 & - & 3.28 & - & - & 4.43 & 0.82 & 10.03 \\
\hline Cement kiln dust (CKD) & 1.90 & 0.10 & 1.16 & 0.27 & 62.6 & 0.01 & 1.40 & 0.01 & 0.55 & - & - & 32.0 \\
Hydrated lime (L) & & & & & & & &
\end{tabular}

LOI $=$ Los of ignition.

calcium hydroxide, $\mathrm{Ca}(\mathrm{OH})_{2}$. It is produced by reacting quicklime $(\mathrm{CaO})$ with sufficient water to form a white powder.

\subsection{Methods}

Chemical analysis, X-ray fluorescence (XRF), of the used cement kiln dust and the hydrated lime was carried out. Chemical stabilization program (Laboratory) using cement kiln dust and cement kiln dust with lime was conducted including three main steps. The first step was a preparation of the soil sample; soil sample was dried in the air and then it was put into the oven at $50^{\circ} \mathrm{C}$ for 24 hours. The dried soil was crushed in crushing-machine. The second step was a determination of an optimum cement kiln dust and an optimum cement kiln dust with lime contents to stabilize the studied soil using $\mathrm{pH}$-test [17]. The third step was a preparation of the cement kiln dust-stabilized samples compacted at a maximum dry density and an optimum water content and a preparation of the cement kiln dust with lime-stabilized samples compacted at a maximum dry density and an optimum water content. There are two methods to evaluate the geotechnical properties of the stabilized soils. The first method is destructive and including a measurement of several geotechnical parameters like unconfined compressive strength.

The second method is nondestructive and including a measurement of ultrasonic velocity of the studied soil before and after the chemical stabilization. Geotechnical properties including plasticity [18], compaction parameters [19], unconfined compressive strength (qu) [20], ultrasonic velocities including both longitudinal [21] and shear velocities using JAMES instrument (V-METER MK IV), free swelling percent [22] of the studied soil were measured before and after the treatment. Microstructural changes of the studied soil were examined using scanning electron microscope (SEM) before and after the treatment, where the changes of the microstructure and the microstructural development of the soils due to chemical stabilization play a significant role in the geotechnical properties and the mechanical behavior of the stabilized soils [2].

\section{Results}

\subsection{Chemical Analysis Results}

Table 2 illustrated the relation between $\mathrm{pH}$-values and chemical additives according to $\mathrm{pH}$-test [17]. The results showed that the optimum content of the cement kiln dust was $16 \%$ (CKD) and the optimum content of the cement kiln dust with lime, to stabilize the studied soil, was $14 \%$ (CKD) with 3\% (L).

\subsection{Geotechnical Results}

\subsubsection{Plasticity Test Results}

Table 3 showed the values of Atterberg limits including liquid limit (LL), plastic limit (PL) and plasticity index (PI) of the studied soil before and after the addition of the chemical additives. The addition of cement kiln dust led to a reduction of these values from $91.60 \%, 61.00 \%$ and $30.60 \%$ to $34.50 \%, 28.20 \%$ and $6.30 \%$ respectively. The addition of cement kiln dust with lime resulted also in a reduction of these values to $32.40 \%, 27.30 \%$ and $5.10 \%$ respectively.

\subsubsection{Compaction Test Results}

Figure 5 illustrated the moisture-density curves (compaction or Proctor curves). The results showed that the maximum dry density (Proctor density) and the optimum water content of the natural studied soil were $1.79 \mathrm{~g} / \mathrm{cm}^{3}$ and $15.10 \%$ respectively. In general, the addition of cement kiln dust resulted in an increase in the optimum moisture content from $15.10 \%$ to $25.00 \%$ and a decrease in the maximum dry density from 1.79 to $1.68 \mathrm{~g} / \mathrm{cm}^{3}$. The addition of cement kiln dust with lime led to an increase in the optimum moisture content to $27.00 \%$ and a decrease in the maximum dry density to $1.65 \mathrm{~g} / \mathrm{cm}^{3}$ (Table 3 ). The bell-shaped compaction curve of the studied soil was converted to flattened-shaped curves.

\subsubsection{Unconfined Compressive Strength Test Results}

Table 3 showed the results of unconfined compressive strength tests of both natural compacted and stabilized soil. The addition of the optimum cement kiln dust content to the study soil led to an increment of the strength value from 209.00 to $1528.80 \mathrm{KN} / \mathrm{m}^{2}$ after 7 day curing. Increasing curing time from 7 to 28 days led to an increase in the qu-value to $2292.99 \mathrm{KN} / \mathrm{m}^{2}$. The addition of optimum cement kiln dust with lime content resulted in an increment of the strength value to $1656.06 \mathrm{KN} / \mathrm{m}^{2}$ after 7 day curing. Increment of the curing time from 7 to 28 days led to an increase in the qu-value to 2802.55 $\mathrm{KN} / \mathrm{m}^{2}$. Figure 6 illustrated the stabilized samples after 
Table 2. Relation between the pH-values and the optimum contents of the chemical additives.

\begin{tabular}{|c|c|c|c|}
\hline Type of chemical additive & Percent (\%) & $\mathrm{pH}$-value & Temperature \\
\hline Without additive & 0 & 8.8 & 25 \\
\hline \multirow{9}{*}{ Cement kiln dust (CKD) } & $8 \mathrm{CKD}$ & 12.20 & 25 \\
\hline & $10 \mathrm{CKD}$ & 12.26 & 25 \\
\hline & 12 CKD & 12.33 & 25 \\
\hline & $14 \mathrm{CKD}$ & 12.39 & 25 \\
\hline & $16 \mathrm{CKD}^{*}$ & 12.40 & 25 \\
\hline & $18 \mathrm{CKD}$ & 12.44 & 25 \\
\hline & 20 CKD & 12.46 & 25 \\
\hline & 22 CKD & 12.48 & 25 \\
\hline & $24 \mathrm{CKD}$ & 12.49 & 25 \\
\hline \multirow{8}{*}{ Cement kiln dust with lime $(\mathrm{CKD}+\mathrm{L})$} & $8 \mathrm{CKD}+3 \mathrm{~L}$ & 12.31 & 25 \\
\hline & $10 \mathrm{CKD}+3 \mathrm{~L}$ & 12.34 & 25 \\
\hline & $12 \mathrm{CKD}+3 \mathrm{~L}$ & 12.37 & 25 \\
\hline & $14 \mathrm{CKD}+3 \mathrm{~L}^{*}$ & 12.40 & 25 \\
\hline & $16 \mathrm{CKD}+3 \mathrm{~L}$ & 12.44 & 25 \\
\hline & $20 \mathrm{CKD}+3 \mathrm{~L}$ & 12.49 & 25 \\
\hline & $22 \mathrm{CKD}+3 \mathrm{~L}$ & 12.50 & 25 \\
\hline & $24 \mathrm{CKD}+3 \mathrm{~L}$ & 12.51 & 25 \\
\hline
\end{tabular}

${ }^{*}=$ Optimum content.

Table 3. Geotechnical properties of the studied expansive soil.

\begin{tabular}{|c|c|c|c|c|c|c|c|c|c|c|c|c|}
\hline \multirow[b]{2}{*}{ Sample type } & \multirow[b]{2}{*}{$\begin{array}{c}\mathrm{MDD} \\
\left(\mathrm{g} / \mathrm{cm}^{3}\right)\end{array}$} & \multirow[b]{2}{*}{$\begin{array}{c}\text { OWC } \\
(\%)\end{array}$} & \multirow[b]{2}{*}{$\begin{array}{c}\mathrm{Vp} \\
\text { (m/sec) }\end{array}$} & \multirow[b]{2}{*}{ Vp-gain } & \multirow[b]{2}{*}{$\begin{array}{c}\mathrm{Vs} \\
(\mathrm{m} / \mathrm{sec})\end{array}$} & \multirow[b]{2}{*}{ Vs-gain } & \multirow[b]{2}{*}{$\begin{array}{l}\text { qu-value } \\
\left(\mathrm{KN} / \mathrm{m}^{2}\right)\end{array}$} & \multirow[b]{2}{*}{ qu-gain } & \multicolumn{3}{|c|}{ Consistency limits } & \multirow[b]{2}{*}{$\begin{array}{c}\text { Free } \\
\text { swelling } \\
\text { (\%) }\end{array}$} \\
\hline & & & & & & & & & $\begin{array}{l}\mathrm{LL} \\
(\%)\end{array}$ & $\begin{array}{l}\text { PL } \\
(\%)\end{array}$ & $\begin{array}{l}\text { PI } \\
(\%)\end{array}$ & \\
\hline Untreated compacted soil & 1.79 & 15.10 & 699.52 & 0.00 & 1246.63 & 0.00 & 209.00 & 0.00 & 91.60 & 61.00 & 30.60 & 80.00 \\
\hline $\begin{array}{l}\text { Cement kiln dust-treated soil } \\
\text { (7 days curing) }\end{array}$ & & & 1379.22 & 1.97 & 2481.68 & 1.99 & 1528.80 & 7.31 & & & 6.30 & 0.00 \\
\hline $\begin{array}{l}\text { Cement kiln dust with } \\
\text { lime-treated soil } \\
\text { (7 days curing) }\end{array}$ & & & 905.87 & 1.29 & 1607.52 & 1.29 & 1656.06 & 7.92 & & & 5.10 & 0.00 \\
\hline $\begin{array}{l}\text { Cement kiln dust with } \\
\text { lime-treated soil } \\
\text { (28 days curing) }\end{array}$ & 1.65 & 27.00 & 2154.94 & 3.10 & 3829.20 & 3.10 & 2802.55 & 13.41 & 32.40 & 27.30 & & 0.00 \\
\hline
\end{tabular}

MDD = Maximum Dry Density; OWC = Optimum Water Content; Vp = Longitudinal Velocity; Vs = Shear Velocity.

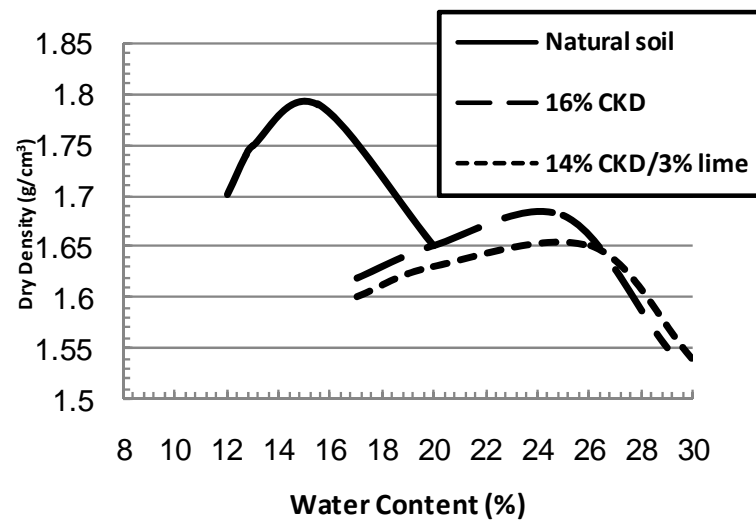

Figure 5. Compaction curves of the natural and the treated soil.

the unconfined compressive strength test.

\subsubsection{Ultrasonic Velocities Test Results}

Table 3 illustrated the ultrasonic velocity values including both longitudinal (Vp) and shear (Vs) wave velocities of both natural and stabilized soil. The addition of the optimum cement kiln dust content to the soil resulted in an increase in both Vp- and Vs-values from 699.52 to $1379.22 \mathrm{~m} / \mathrm{sec}$ and from 1246.63 to $2481.68 \mathrm{~m} / \mathrm{sec}$ after 7 day curing. Increment of the curing time from 7 to 28 days led to an increment of both Vp- and Vs-values to 1983.33 and $3514.65 \mathrm{~m} / \mathrm{sec}$ respectively. The addition of optimum cement kiln dust with lime content to the soil led to an increment of both Vp- and Vs-values from 699.52 to $905.87 \mathrm{~m} / \mathrm{sec}$ and from 1246.63 to 1607.52 $\mathrm{m} / \mathrm{sec}$ after 7 day curing. With increasing curing time from 7 to 28 days, both Vp- and Vs-values were increased to 2154.94 and $3829.20 \mathrm{~m} / \mathrm{sec}$ respectively. 


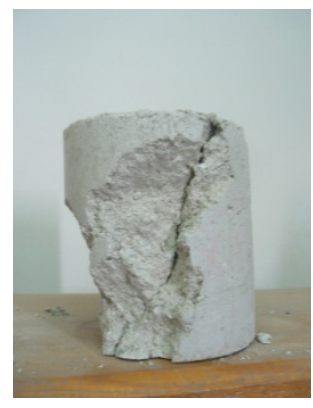

(a)

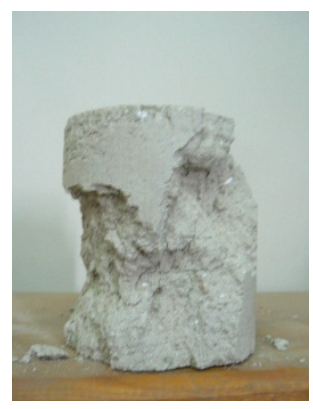

(b)

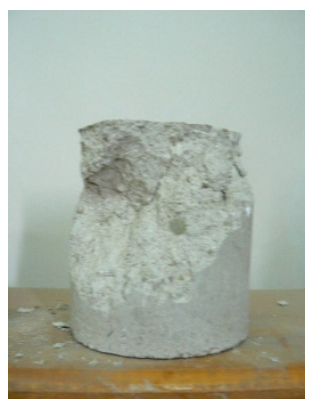

(c)

Figure 6. Treated samples after qu-tests; (a) stabilized sample after 7 days curing (CKD); (b) stabilized sample after 7 days curing (CKD with $L$ ); and (c) stabilized sample after 28 days curing (CKD with $L$ ).

\subsubsection{Free Swelling Test Results}

Table 3 showed the free swelling percent values of the studied expansive soil before and after the treatment. The results showed that the free swelling percent value of the natural studied soil were $80.00 \%$. After 7 and 28 days curing, the addition of cement kiln dust and cement kiln dust with lime led to a reduction of the free swelling percent from $80.00 \%$ to $0.00 \%$.

\subsection{Microstructural Changes}

Figure 7(a) illustrated the micrograph of the natural expansive clayey silt which showed flaky arrangements of clay particles as matrix between detrital fine grains (silt and fine sand) [1]. Figure 7(b) showed the micrograph of the stabilized soil with 16\% CKD cured for 7 days. The micrograph showed crumbs of floccules with a porous nature and cementitous compounds, calcium aluminum hydrate $(\mathrm{CAH})$ and calcium silicate hydrate $(\mathrm{CSH})$, coating the relics of the silt particles and the flocs. The edges of the relics of the particles were attacked by cement kiln dust and their boundaries had a ragged-form.

Additionally, the reaction of cement kiln dust with clay led to a formation of an aggregate of various sizes and that was responsible for the increase in porosity of the soil system. Similar microfabric structure was observed by [1,2,23-27].

Figure 7(c) illustrated the micrograph of the treated soil with 14\% CKD with 3\% L cured for 7 days. The microstructure showed both the fibrous and the gel hydration reaction products. The hydration reaction products coated both the cement kiln dust and the soil-particles and filled the voids partially between the particles. The microstructure is highly porous due to the flocculation and the increase in the diameter of the flocs by production of the cementitous compounds surrounded these flocs.

Figure 7(d) illustrated the micrographs of the stabilized soil with $16 \%$ CKD cured for 28 days. The micrograph showed cementitious compounds (due to pozzolanic reaction) coated and joined the soil and the cement kiln dust particles. The pores were partially filled with the cementitious compound and were relatively reduced. Figure 7(e) showed the micrograph of the treated soil with $14 \%$ CKD with $3 \% \mathrm{~L}$ cured for 28 days. The microstructure had relatively small pores due to a formation of a large amount of cementitious compound resulted from the stronger reaction between cement kiln dust and lime together with the soil.

\section{Discussions and Conclusions}

The optimum content of the cement kiln dust to stabilize the studied soil was $16 \%$ and the optimum content of the cement kiln dust with lime was 14\% (CKD) with 3\% (L), using pH-test [17]. The addition of the optimum cement kiln dust resulted in a reduction of the liquid limit (LL), the plastic limit (PL) and the plasticity index (PI) values from $91.60 \%, 61.00 \%$ and $30.60 \%$ to $34.50 \%$, $28.20 \%$ and $6.30 \%$ respectively. The addition of the cement kiln dust with lime also led to a reduction of these values to $32.40 \%, 27.30 \%$ and $5.10 \%$ respectively. This reduction was due to a decrease in the thickness of the double layer of the clay particles. That is because of cation exchange reaction, which causes an increase in the attraction force leading to a flocculation of the particles [28]. The maximum dry density (Proctor density) and the optimum water content of the natural studied soil were $1.79 \mathrm{~g} / \mathrm{cm}^{3}$ and $15.10 \%$ respectively. Generally, the addition of the cement kiln dust to the studied soil led to an increment of the optimum moisture content from $15.10 \%$ to $25.00 \%$ and a decrement of the maximum dry density from 1.79 to $1.68 \mathrm{~g} / \mathrm{cm}^{3}$. Similar results were recorded by the addition of the cement kiln dust with lime where the optimum moisture content was increased to $27.00 \%$ and the maximum dry density was reduced to $1.65 \mathrm{~g} / \mathrm{cm}^{3}$. The bell-shaped compaction curve of the studied soil was converted to flattened-shaped curve. The typical flattening of the compaction curve of the studied stabilized soil makes it easier to achieve the required density over a wider range of possible moisture contents [2]. The change in the shape and characteristics of the peak of the com- 


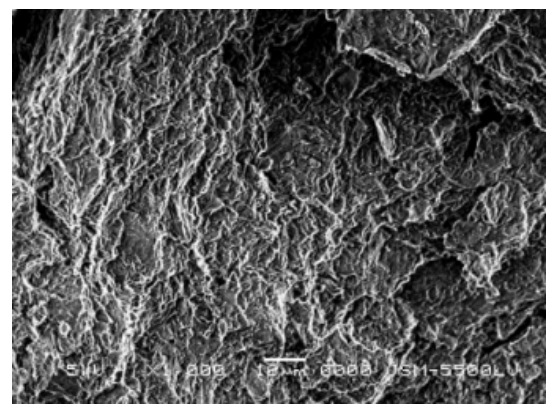

(a)

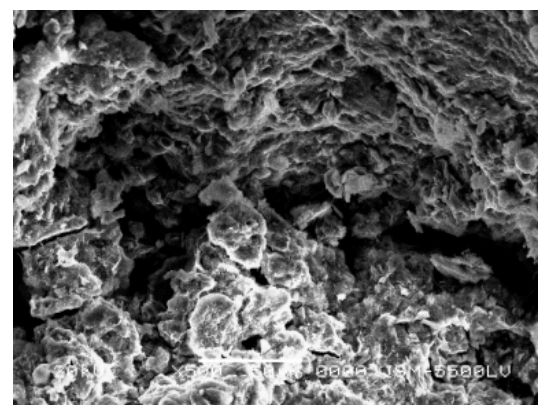

(b)

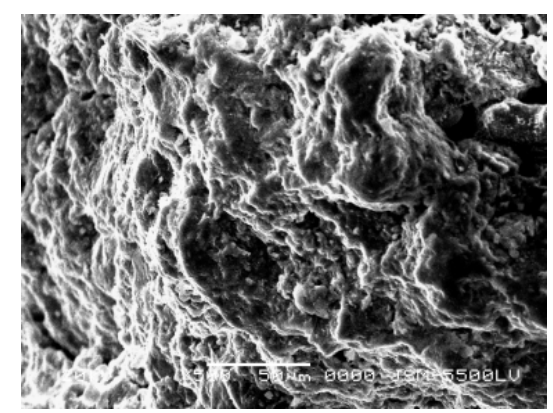

(c)

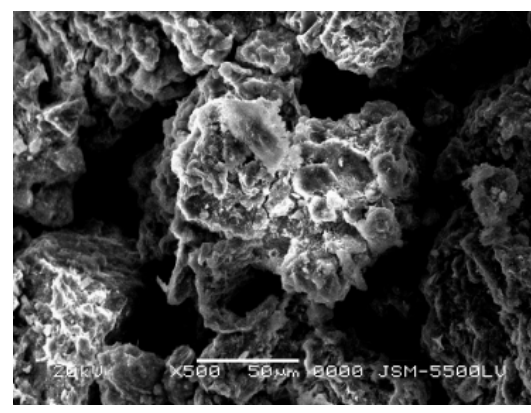

(d)

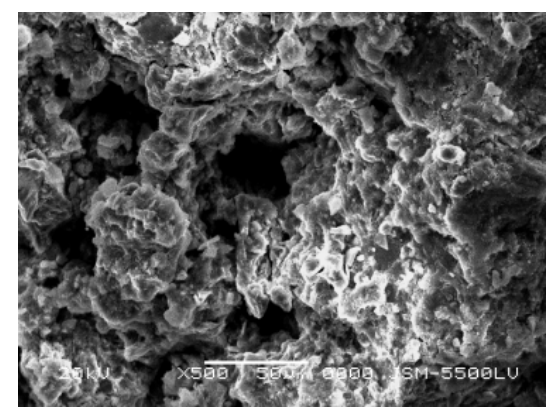

(e)

Figure 7. Micrographs of natural and stabilized soil using scanning electron microscope (SEM).

paction curves can allow for significant savings in time, effort and energy [29]. The addition of the cement kiln dust resulted in an increase in the strength value from 209.00 to $1528.80 \mathrm{KN} / \mathrm{m}^{2}$ after 7 -day curing. Increasing curing time from 7 to 28 days resulted in an increase in the strength value to $2292.99 \mathrm{KN} / \mathrm{m}^{2}$. The strength gain (strength of stabilized soil/ strength of natural compacted soil) was also increased from 7.31 to 10.97 . The addition of the cement kiln dust with lime led to an increment of the strength value to $1656.06 \mathrm{KN} / \mathrm{m}^{2}$ after 7 -day curing. Increment of the curing time from 7 to 28 days resulted in an increase in the strength value to $2802.55 \mathrm{KN} / \mathrm{m}^{2}$. The strength gain was also increased from 7.92 to 13.41 . The mechanical behavior of the stabilized soil had a brittle behavior due to a formation of cementitous compounds. The formed cementitious compounds (as a result of the chemical reactions between the silica and the alumina and the additives) reduced the volume of the void spaces and joined the soil particles [2].

$$
\begin{array}{cc}
\mathrm{Ca}^{++}+2(\mathrm{OH})+\mathrm{S}_{\mathrm{i}} \mathrm{O}_{2} & \rightarrow \text { CSH Calcium silicate hydrate } \\
(\mathrm{Silica}) & (\mathrm{Gel}) \\
\mathrm{Ca}^{++}+2(\mathrm{OH})+\mathrm{Al}_{2} \mathrm{O}_{3} & \rightarrow \text { CAH Calcium aluminumhydrate } \\
\text { (Alumina) } & \text { (Fibrous) }
\end{array}
$$

The addition of the cement kiln dust to the studied soil resulted in an increase in both Vp- and Vs-values from 699.52 to $1379.22 \mathrm{~m} / \mathrm{sec}$ and from 1246.63 to 2481.68 $\mathrm{m} / \mathrm{sec}$ after 7-day curing. Increment of the curing time from 7 to 28 days led to an increment of both Vp- and
Vs-values to 1983.33 and $3514.65 \mathrm{~m} / \mathrm{sec}$, respectively. The addition of the cement kiln dust with lime to the soil led to an increment of both Vp- and Vs-values from 699.52 to $905.87 \mathrm{~m} / \mathrm{sec}$ and from 1246.63 to 1607.52 $\mathrm{m} / \mathrm{sec}$ after 7-day curing. With increasing curing time from 7 to 28 days, both Vp- and Vs-values were increased to 2154.94 and $3829.20 \mathrm{~m} / \mathrm{sec}$ respectively. The increasing of the ultrasonic velocity due to the formation of new cementitous compounds and mineral crystals as a pozzolanic reaction produced through the curing [2].

The addition of cement kiln dust and cement kiln dust with lime led to a decrease in the free swelling value from $80.00 \%$ to zero\% at curing times 7 and 28 days. The reduction of the free swelling due to consumption of the clay minerals during the hydration reaction formed the cementitious compounds. Additionally, the reaction of chemical additives with clay led to a formation of an aggregate of various sizes with low ability for swelling.

The improvements of the engineering properties of the studied soil due to use of the chemical additives can be explained by two basic reactions: short-term reactions consisting cation exchange and flocculation and the longterm reaction named pozzolanic activity. During the first stage of the reaction between the chemical additives and the clay, excesses of calcium ions in lime or in cement kiln dust replace all other monovalent cations in the clay and change the electrical charge density around the clay particles. This results in an increase in the interparticle attraction causing flocculation and aggregation and a consequent decrease in the plasticity of the soil [30]. The 
pozzolanic reaction is time-bound and tempreture dependent. During this process, the high $\mathrm{pH}$ causes silics and alumina to be dissolved out of the structure of the clay minerals and to combine with the calcium (occurred in the cement kiln dust or the lime) to produce the new cementitious compounds calcium silicate hydrates (CSH), calcium aluminate hydrates (CAH), calcium aluminosilicate hydrates (CASH) [30] and others.

Examination of the stabilized soil using scanning electron microscope (SEM) indicated that the microstructures of the tested soil were changed due to the cement kiln dust and the cement kiln dust with lime. The stabilization process caused a formation of a silt-fine sand like structure (open fabric) characterized by a highly porous system. The SEM-micrographs of the natural and the stabilized soil indicated the formation of new cementitous compounds and mineral crystals as a pozzolanic reaction product through the curing. These cementitous compounds have improved the geotechnical properties of the studied soil and reduced the swelling. The influence of the cement kiln dust with lime addition on the soil was greater than the influence of the cement kiln dust alone. Use of the cement kiln dust with small percentage of lime produced more dramatic results, especially after 28 days curing.

Finally, cement kiln dust (as by product of Qena cement plant, at Qift industrial city) contains relatively small percent of sulfates $(4.43 \%)$ and can be utilized to treat and stabilize the expansive fine grained soil as economical (cheaper) alternative to Portland cement and other (expansive) chemical stabilizers. The use of cement kiln dust for chemical stabilization applications is an environmental solution of the problems associated with its disposal process.

\section{Acknowledgements}

Greatly thanks to staff members of Qena faculty of engineering, Al-Azhar University for offering the laboratory facility to conduct the geotechnical tests of this work. Special thanks for the staff members of Qena cement plant for valuable cooperation. Special thanks for Ms. Heba Taha, Ms. Mona Mohamed and Ms. Samar Yousef for laboratory help.

\section{REFERENCES}

[1] H. A. H. Ismaiel and M. M. Badry, "Lime Chmical Stabilization of Expansive Deposits Exposed at El-Kawther Quarter, Sohag Region, Egypt,” Geosciences, Vol. 3, No. 3, 2013, pp. 89-98.

[2] H. A. H. Ismaiel, "Treatment and Improvement of the Geotechnical Properties of Different Soft Fine-Grained Soils Using Chemical Stabilization,” Ph.D. Thesis, Mathematisch-Naturwissenschaftlich-Technischen Fakultät der Martin-Luther-Universität Halle-Wittenberg, 2006.
[3] E. H. Ramadan, “In Situ Chemical Stabilization of Expansive Clay Soil by Lime Additive,” 7th International Colloquium on Structural and Geotechnical Engineering, Ain Shams Uni., Cairo, 1996, pp. 403-419.

[4] T. O. Al-Refeai, "Stabilization Characteristics of Cement Kiln Dust,” Geoengineering in Arid Lands, 2000, pp. 133-137.

[5] M. Zaman, I. G. Lagurous and A. Sayah, "Soil Stabilization Using Cement Kiln Dust,” Proceedings of the 7th International Conference on Expansive Soil, Dallas, 1992.

[6] Tensar Technical Note, "Chemical and Mechanical Stabilization of Sub-Grades and Flexible Pavement Sections," TTN, BR 10, 1998.

[7] B. Das, "Principles of Geotechnical Engineering," 3rd Edition, PWS-Kent Publishing Company, Boston, 1994.

[8] J. Bowles, "Engineering Properties of Soil and Their Measurements,” 4th Edition, McGraw-Hill, Boston, 1992.

[9] M. E. Mustafa, "Computerized Analysis of Geologic Structures in Central Eastern Desert, Egypt and Their Role in Distribution of Radioactive Mineralization,” Ph.D. Thesis, Cairo Uni., Egypt, 1979.

[10] A. A. Abdelmoneim, "Hydrogeology of the Nile Basin in Sohag Province,” Master Thesis, Faculty of Sci., Assiut Uni., Egypt, 1988.

[11] A. M. Youssef, "Mapping the Pliocene Clay Deposits Using Remote Sensing and Its Impact on the Urbanization Developments in Egypt, Case Study, East Sohag Area," Geotechnical and Geological Engineering, No. 26, 2008, pp. 579-591.

[12] F. E. Salwa, B. B. Abdel Aziz and A. Z. El-Sayed, "Hazards Mitigation and Natural Resources Evaluation around Sohag-Safaga Highway, Eastern Desert, Egypt,” Egyptian Journal of Remote Sensing and Space Sciences, Vol. 14, No. 1, 2011, pp. 15-28. http://dx.doi.org/10.1016/j.ejrs.2011.01.001

[13] H. A. H. Ismaiel, M. M. Askalany and M. M. Badry, "Geotechnical Propertied and Classification of Both NonExpansive and Expansive Soils Exposed along the New Upper Egypt-Red Sea Road, Eastern Desert, Egypt,” Scientific Journal of Banha University, No. 6, 2011, pp. 1-18.

[14] A. Aly, "Assessment of Drying-Wetting Cycles for Mitigation the Potential of Expansive Soil in Upper Egypt," Journal of Applied Sciences Research, No. 12, 2009, pp. 2277-2284.

[15] M. A. Sakr, M. A. Shahin and M. M. Yasser, "Utilization of Lime for Stabilizing Soft Clay Soil of High Organic Content,” Geotechnical and Geological Engineering, No. 27, 2009, pp. 105-113.

[16] Conoco Inc., "Stratigraphic Lexicon and Explanatory Notes to the Geological Map of Egypt 1: 500000,” Coy H. Squyres General Chairman Map Project, Cairo, 1986.

[17] J. L. Eades and R. E. Grim, “A Quick Test to Determine Lime Requirements for Lime Stabilization,” Highway Research Board, National Research Council, Washington DC, No. 139, 1996, pp. 61-72.

[18] AASHTO, T 90, "Standard Method of Test for Determining the Plastic Limit and Plasticity Index of Soils," 
Single User Digital Publication, American Association of State Highway and Transportation Officials, Washington DC, 2010.

[19] AASHTO, T 99, "Standard Method of Test for MoistureDensity Relations of Soils Using a 2.5kg (5.5-lb) Rammer and a 305-mm (12-in.) Drop," Single User Digital Publication, American Association of State Highway and Transportation Officials, Washington DC, 2010.

[20] AASHTO, T 208, "Standard Method of Test for Unconfined Compressive Strength of Cohesive Soil," Single User Digital Publication, American Association of State Highway and Transportation Officials, Washington DC, 2010.

[21] N. Yesiller, J. L. Hanson, A. T. Rener and M. A. Usmen, "Ultrasonic Testing for Evaluation of Stabilized Mixtures," Geomaterials, Transportation Research Record, No. 1757, 2001, pp. 32-39.

[22] Egyptian Code, "Egyptian Code of Soil Mechanics," Foundations Carrying out and Designation, Part 2, Laboratory Tests, 6th Edition, 2001.

[23] J. L. Eades and R. E. Grim, "Reaction of Hydrated Lime with Pure Clay Minerals in Soil Stabilization," Highway Research Board, No. 262, 1960, pp. 51-63.

[24] J. B. Croft, "The Processes Involved in the Lime Stabilization of Clay Soils," Proceedings of Australian Road Research Board, Part 2, 1964, pp. 1169-1203.
[25] R. S. Narasimha and G. Rajasekaran, "Strength and Deformation Behavior of Lime Treated Marine Clays," Proceedings of 3rd International Offshore and Polar Engineering, Singapore, 1993, pp. 185-196.

[26] G. Rajasekaran, K. Murali and R. Srinivasarghavan, "Fabric and Mineralogical Studies on Lime Treated Marine Clays,” Ocean Engineering, Vol. 24, No. 3, 1995, pp. 227-234. http://dx.doi.org/10.1016/S0029-8018(96)00010-8

[27] G. Rajsekaran and R. S. Narasimha, "Particle Size Analysis of Lime-Treated Marine Clays,” Geotechnical Testing Journal, Vol. 21, No. 2, 1998, pp. 109-119. http://dx.doi.org/10.1520/GTJ10749J

[28] Z. Nalbantoglu and E. Gucbilmez, "Utilization of an Industrial Waste in Calcareous Expansive Clay Stabilization,” Geotechnical Testing Journal, Vol. 25, No. 1, 2002, pp. 8-84.

[29] P. Nicholson, V. Kashyap and C. Fuji, "Lime and Fly Ash Admixture Improvement of Tropical Hawaiian Soils," Transportation Research Record, Washington DC, No. 1440, 1994, pp. 71-78.

[30] Z. Nalbantoglu and E. Gucbilmez, "Improvements of Calcareous Expansive Soils,” Journal of Arid Environments, Vol. 47, No. 4, 2001, pp. 453-463. http://dx.doi.org/10.1006/jare.2000.0726 